\title{
The Challenges of Dealing with Nitrogen Pollutants in Groundwater
}

\author{
Los desafíos de tratar con contaminantes nitrogenados en aguas subterráneas
}

\section{Os desafios de tratar com poluentes nitrogenados em águas subterrâneas}

Stephanye Zarama-Alvarado ${ }^{1}$

Received: june de 2017

Accepted: august de 2018

Citation: Zarama-Alvarado, S. (2018). The Challenges of Dealing with Nitrogen Pollutants in Groundwater. Revista Científica, 33(3), 230-242. Doi: https://doi.org/10.14483/23448350.13545

\begin{abstract}
Nitrogen compounds are being injected into the environment by human activities, which are altering the global nitrogen cycle and, thus, water systems. There is principally serious growing concern about the actual environmental consequences of the nitrogen pollutants in groundwater since a safe supply of clean water is needed for human consumption. Recent observations in the field of measurements and studies in the laboratory suggest that there are limitations of effective methods that detect and quantify biogeochemical reactions of nitrogen loss occurred in this aquatic body. This review explores our understanding of nitrogen pollutants on groundwater, taking into consideration the biogeochemical reactions of nitrogen cycle, and the limitations and advantages of analytical methods used in the detection of nitrogen compounds.
\end{abstract}

Keywords: analytical methods, groundwater, isotopic labeling, nitrogen cycle, pollutants.

\section{Resumen}

Los compuestos de nitrógeno son diseminados en el medio ambiente por actividades humanas que alteran el ciclo del nitrógeno y, con ello, los sistemas de agua. Hay una creciente preocupación sobre las consecuencias ambientales de los contaminantes nitrogenados en aguas subterráneas debido a que el abastecimiento seguro de agua potable limpia es requerido para el consumo humano. Recientes observaciones en campo y estudios en el laboratorio sugieren que hay limitaciones de métodos efectivos que detecten y cuantifiquen las reacciones biogeoquímicas de las pérdida de nitrógeno ocurrida en este manto acuífero. Esta revisión explora nuestra comprensión de los contaminantes de nitrógeno en aguas subterráneas, tomando en consideración las reacciones biogeoquímicas del ciclo del nitrógeno y las limitaciones y ventajas de los métodos analíticos utilizados en la detección de los compuestos nitrogenados.

Palabras clave: agua subterránea, contaminantes, nitrogen cycle, marcador isotópico, métodos de análisis.

University of Massachusetts Amherst. szaramaalvar@umass.edu 


\section{Resumo}

Os compostos nitrogenados estão sendo injetados no meio ambiente por atividades humanas que alteram o ciclo do nitrogênio e, com ele, os sistemas hídricos. Existe uma crescente preocupação com as consequências ambientais dos poluentes nitrogenados nas águas subterrâneas, porque o fornecimento seguro de água potável é necessário para o consumo humano. Em observações recentes no campo de medições e estudos em laboratório, eles sugerem que existem limitações de métodos efetivos que detectam e quantificam as reações biogeoquímicas da perda de nitrogênio ocorridas neste manto aquífero. Esta revisão explora nossa compreensão de contaminantes nitrogenados em águas subterrâneas, levando em consideração as reações biogeoquímicas do ciclo do nitrogênio, e as limitações e vantagens dos métodos analíticos usados na detecção de compostos nitrogenados.

Palavras-chaves: aguas subterrâneas, ciclo de nitrogênio, marcador isotópica, métodos de análise, poluentes.

\section{Introdution}

The right nitrogen compounds circulating in Earth determine the existence of life. Human activities are causing the alteration of the global nitrogen circulation, because increasing quantities of nitrogen compounds are being introduced into air, soil and aquatic ecosystems in the last few years (Ghaly and Ramakrishnan, 2015; Fields, 2004). In the planet, nitrogen is found in non-reactive and reactive forms. The non-reactive form of nitrogen is $N_{2}$, which does not contribute to environmental impact. In contrast, reactive forms of nitrogen that come from the fixation of $\mathrm{N}_{2}$, can be the root of strong environmental effects. The accumulation of reactive nitrogen compounds, due to especiaIly the production of fertilizers and by-products of combusting fossil fuels, may cause grave impacts on human health, smog, acid rain, soil, forest dieback, biodiversity, global warming and water quality (Castner et al., 2017; Fields, 2004).

Particularly, the infiltration of reactive nitrogen in drinking water is carried out through runoff from livestock and fertilizers, which arrives to the aquifers that are the principal reservoirs of groundwater (Sampat, 2000). The growing pollution of groundwater sources by reactive nitrogen concentrations has been reported in the last three decades (Castner et al., 2017; Rivett, Buss, Morgan, Smith and Bemmet, 2008). This has set alarm bells ringing about the need to prevent the increase of reactive nitrogen concentrations in groundwater due to the effects on human health in most industrialized nations (Kobus and Kinzelbach, 1989). In order to preserve drinking water, the quantification of nitrogen loss rates in groundwater is paramount. However, the complex and dynamic biogeochemical network of groundwater has not enabled the development of effective methods that measure its nitrogen processes. Therefore, the aim of this review is to examine how nitrogen pollutants, principally nitrate and ammonium, are affecting the microbiological processes of the nitrogen cycle in groundwater and the strengths and weakness of developing effective methods for their detection.

\section{Nitrogen pollutants: nitrate and ammonium}

The pollution in groundwater caused by nitrate $\left(\mathrm{NO}_{3}^{-}\right)$has been becoming an emerging concern worldwide since the 1970s (Spalding, Exner, Martin, and Snow, 1993; Rivett et al., 2008). Even though nitrate in lower concentrations is non-toxic in drinking water, the risk from long exposure may cause health problems such as hypertension, stomach cancer and methemoglobinemia in human infants (baby blue disease) (Almasri and Kaluarachchi, 2004) since it is suspected carcinogen (Kendall, Elliott, and Wankel, 2007). To improve the drinking water quality, the World Health Organization (WHO) established a limit of $10 \mathrm{mg}-\mathrm{N} / \mathrm{I}$ for nitrate concentrations in 1993 (U.S EPA, 2017). Different developed countries have taken important septs; Germany, for instance, monitors the nitrate concentrations of potable water setting a limit value of $15 \mathrm{mg} / \mathrm{l}$ at $15 \%$ of all groundwater control points (UBA, 2014). In the case of developing 
countries, nitrate concentrations are not constantly monitored. Nitrate is also the most studied pollutant compared to ammonium $\left(\mathrm{NH}_{4}^{+}\right)$in groundwater (McMahon and Bölhke, 2006) due to low levels of ammonium in this natural waterbody (Schilling, 2002). For instance, the United States Environmental Protection Agency (U.S EPA) has not established a maximum contaminant level (MCL) for ammonia in drinking water. However, the National Academy of Science recommends, and many European nations have adopted, a drinking water standard of $0.5 \mathrm{mg} / \mathrm{l}$ (Twort et al., 2000). Ammonium levels are regulated via oxidation to nitrate in the unsaturated zone and attenuated by biological uptake and sorption (Schilling, 2002). According to Aravena and Robertson (1998), the high ammonium levels initially present in raw sewage cease to exist in shallow groundwater plumes emanating from septic system. The disinfection efficiency of drinking water systems may be altered by ammonium due to the formation of nitrite producing odour and taste problems on the water (Canter, 1996). The WHO reported that natural ammonium levels produced by the decay of buried organic matter are frequently less than $0.2 \mathrm{mg}-\mathrm{N} / \mathrm{l}$ in groundwater (U.S EPA, 2017). Elevated ammonium levels in natural waters may indicate pollution caused by anthropogenic sources such as sewage effluent, leaking manure lagoons, and landfill leachate (Christensen et al., 2001). For instance, the high ammonium concentrations of about $61 \mathrm{mg} / \mathrm{l}$ are found on a leachate from the KL landfill in Kalamazoo, Michigan (Kehew and Passero, 1990). The primary consequence of the high ammonium concentration in groundwater is the alteration of the chemical and biological properties of water by a frequent eutrophication and hypoxia (Vitousek et al., 1997).

The principal sources contributing to the increase of nitrate and ammonium levels in groundwater are the agricultural practices such as mineralization of urea, degradation of organically bound nitrogen and dissociation of ammonium nitrate fertilizer (Clark et al., 2008), which also cause emission of greenhouse gases (i.e. $\mathrm{N}_{2} \mathrm{O}$ ) and climate change
(Almasri and Kaluarachchi, 2004). There are other sources from localized activities that might contribute to the pollution of groundwater by nitrate and ammonium. They include septic effluent (Aravena and Robertson, 1998) atmospheric deposition, spreading of manure and sewage (Wakida and Lerner, 2005) and municipal wastewater (Christensen et al., 2000). Previous studies have reported that the attenuation of nitrate and ammonia is masked by dilution through dispersion and mixing (Domenico and Schwartz, 1998). For instance, the elevated nitrate and ammonium levels decrease over time in groundwater from North America, Caribbean and Europe during the time periods of one to thirty years (Widory et al., 2004). Furthermore, new reports suggest that denitrification and anaerobic ammonium oxidation (ANAMMOX) as the major responsible processes involved in the removal of these $\mathrm{N}$-compounds in the nitrogen cycle, based on molecular and geochemical evidences (Clark et al., 2008; Seitzinger et al., 2006). Although denitrification has been extensively studied, the significance of anammox may have been largely overlooked. A better understanding of the nitrogen elimination in groundwater is essential to determine the potential impact of contaminants on water supplies, which is extremely important for public health, drinking water providers and society.

\section{Nitrogen cycle}

The global nitrogen cycle is defined by microbial processes produced in oxic and anoxic conditions, which maintain a small pool of fixed nitrogen in continues exchange with the atmospheric $\mathrm{N}_{2}$ reservoir (figure 1) (Thamdrup and Dalsgaard, 2002).

Redox reactions include the transfer of electrons between molecules by means of changing the molecular oxidation state. Groundwater involves a series of the redox reactions facilitated by microorganisms. Biologically, mediated redox reactions lead to nitrogen isotope fractionation and regulate complex nitrogen dynamics and release gases in soils as do lightning and biomass burning. 
The availability of nitrogen is principally represented by the existence of nitrate, nitrite, ammonium and organic nitrogen, which are generally grouped together as fixed $N$. Denitrification, anammox, dissimilatory nitrate reduction to ammonium (DNRA), and nitrification are the microbial processes involved in the removal of nitrogen in the nitrogen cycle.

\section{A) Denitrification}

Biological denitrification is considered to be the most significant primary mechanism of nitrate mass removal through a series of intermediate gaseous nitrogen oxide products performed by a large group of heterotrophic bacteria in anaerobic conditions (eq.1) (Burt, Matchett, Goulding, Webster and Haycock, 1999). The study of this process has been principally investigated in soils for more than a century in comparison with groundwater, which started only some decades ago (Korom, 1992).

$$
2 \mathrm{NO}_{3^{-}}+10 \mathrm{e}^{-}+12 \mathrm{H}^{+} \rightarrow \mathrm{N}_{2}+6 \mathrm{H}_{2} \mathrm{O}
$$

The nitrate oxidation is mediated by a denitrifying bacteria that uses oxidized forms of nitrogen as a terminal electron acceptor for organic carbon metabolism during respiration (Seitzinger et al., 2006). Four key enzymes carry out the sequence of nitrate reduction to nitrogen gas, which are nitrate reductase, nitrite reductase, nitric oxide reductase and nitrous oxide reductase (Codispoti and Richards, 1976). Nitrate reductase converts nitrate to nitrite $\left(\mathrm{NO}_{2}^{-}\right)$, nitrite reductase reduces nitrite to nitric oxide $(\mathrm{NO})$, which itself is reduced to nitrous oxide $\left(\mathrm{N}_{2} \mathrm{O}\right)$ via nitric oxide reductase, and finally nitrous oxide reductase converts nitrous oxide to dinitrogen (eq. 2).

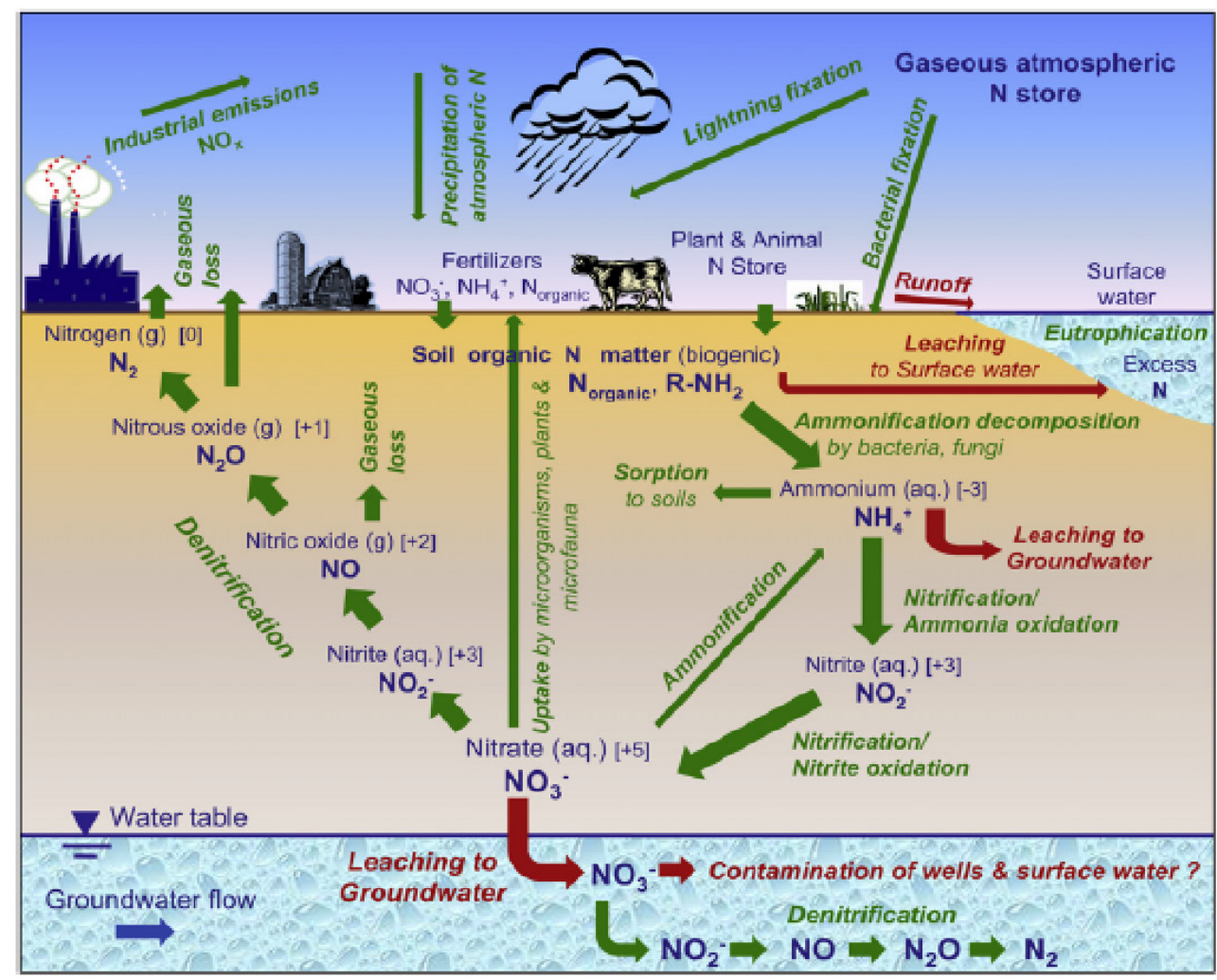

Figure 1. Microbial nitrogen cycle and its influence upon the water environment.

Source: Rivett et al. (2008). 
nitrate concentrations, the observation of appropriate redox conditions and presence of anammox microorganisms in vivo, as well as stable isotope techniques. The study of anammox in situ provides challenges due to the necessity of understanding all the sources involved in groundwater. Nitrite is used and produced during anammox, denitrification, and nitrification processes, while ammonium is used and produced during anammox and DNRA.

\section{C) Dissimilatory Nitrate Reduction to Ammonium}

Two different processes of nitrate reduction are contained within the nitrogen cycle: denitrification and dissimilatory nitrate reduction to ammonium. According to Korom (1992), the term "assimilatory reduction" refers to the incorporation of a compound into organic material as part of its reduction, in comparison to the dissimilatory reduction, which performs the reduction of a compound for its yield to a different inorganic compound. DNRA is known as a short circuit in the biological nitrogen cycle (Cole and Brown, 1980) due to the direct conversion of nitrate and nitrite to ammonium (eq. 6) by passing nitrogen fixation and denitrification by a group of heterotrophic organisms in anaerobic conditions. In DNRA, nitrate and nitrite reduction are catalysed by fermentative bacteria belonging to the genre Thioploca and Thiomargarita (Korom, 1992).

$$
2 \mathrm{H}^{+}+\mathrm{NO}_{3^{-}}+2 \mathrm{CH}_{2} \mathrm{O} \rightarrow \mathrm{NH}_{4^{+}}+2 \mathrm{CO}_{2}+\mathrm{H}_{2} \mathrm{O}
$$

Although the DNRA is an alternative pathway of nitrate reduction, studies have reported that DNRA in groundwater is less common than denitrification. The availability of organic matter plays an important role in the partitioning of nitrate between denitrification and DNRA. Studies suggest that there is a preference for denitrification when carbon (electron donor) supplies are limited and for DNRA when nitrate (electron acceptor) supplies are limited (Korom, 1992). One of the most important differences between denitrification and DNRA is the obtained product of the nitrate conversion. While denitrification conserves nitrogen in the ecosystem, DNRA converts nitrate into another mineral $\mathrm{N}$-form less mobile as ammonium (Tiedje, 1988). Understanding the function of DNRA as producer of ammonium decreasing nitrate concentrations in groundwater has been an advantage from a remediation perspective.

\section{D) Nitrification}

Nitrification has been extensively investigated in natural environments such as soils, estuaries, lakes and open ocean environments due to its importance in the global nitrogen cycle (Sumner, Rolston, and Bradner, 1998). There are two steps of nitrification, which convert ammonia to nitrate by distinct types of microorganisms in anaerobic conditions. No known organism is able to execute both reactions. In the first step, the oxidation of ammonia to nitrite is performed by two groups of aerobic ammonia oxidizers such as ammonia-oxidizing bacteria (AOB) and ammonia-oxidizing archaea (AOA) that belong to the Nitrosomonas and Thaumarchaeota genus (Clark et al., 2008). The equation (7) and (8) are shown the ammonia oxidation that produces a very small quantity of energy via intermediate hydroxylamine $\left(\mathrm{NH}_{2} \mathrm{OH}\right)$ by using two different enzymes known as ammonia monooxygenase and hydroxylamine oxidoreductase (Vajrala et al., 2013).

Ammonia monooxygenase

$$
\mathrm{NH}_{3}+\mathrm{O}_{2}+2 \mathrm{e}-\rightarrow \mathrm{NH}_{2} \mathrm{OH}+\mathrm{H}_{2} \mathrm{O}
$$

Hydroxylamine oxidoreductase

$$
\mathrm{NH}_{2} \mathrm{OH}+\mathrm{H}_{2} \mathrm{O} \rightarrow \mathrm{NO}_{2}-+5 \mathrm{H}++4 \mathrm{e}-
$$

In the second step, the oxidation of nitrite into nitrate is carried out by nitrite oxidizing bacteria belonging to the genus Nitrobacter and Nitrospira (eq. 9) (Simonin et al., 2015). Similar to the first step, the energy generated by the nitrite oxidation is very small (Vajrala et al., 2013). Due to the 
important function of nitrification by using specific enzymes in the nitrogen cycle, ammonia and nitrite oxidizers play a fundamental role in wastewater treatment facilities by removing elevated levels of ammonium, which produce the pollution of drinking water.

$$
\mathrm{NO}_{2}+\frac{1}{1 / 2} \mathrm{O}_{2} \rightarrow \mathrm{NO}_{3}
$$

\section{Analytical methods in nitrogen compounds}

The quantification of the mechanisms of nitrogen processing presupposes a critical role in determining the influence of groundwater nitrogen sources (Tobias, Macko, Anderson, Canuel, and Harvey, 2001). The study of biogeochemical reactions in groundwater, particularly denitrification and anammox, becomes a challenging task due to the difficulty of accessing or detecting the reaction sites, where the specific pathways that result in retention or accelerated losses of nitrogen by multiple ammonium and nitrate sources establish a complex and dynamic microbiological network. Unfortunately, the development of effective methods that guarantee adequate measurements of the involved microbiological processes has not been established so far. Available methods have shown serious drawbacks such as changes in substrate concentrations, lack of sensitivity, disturbances in the physical settings of the process, high spatial and temporal variation of the process or high background concentration (Jahangir et al., 2013). The identification of reaction rates from free living bacteria in groundwater has been enriched by new molecular and analytical approaches through the last years. Although the genetic characterization of new species established a possibility to understand the organism's function in groundwater, for instance quantitative PCR (qPCR), the measurements require to be calibrated as proxies for the reaction rate, and therefore, these rates do not necessarily correlate with their activity influenced by environment conditions (Song and Tobias, 2011). Therefore, chemists and hydrogeologists have tried to address the derivation of the reaction rates by different approaches. The examination of changes in chemical ratios along flow paths from stoichiometrically-related chemical concentrations of reactants and products is an analytical method to identify processes that are involved in groundwater. This method is not always sufficient due to the fact, that the chemical ratios do not provide insight into the sources of pollution.

Another analytical approach to derive reactions rates is the use of in situ tracer experiments coupled to advection-dispersion models, which are focused on the measurement of mass transport of compounds (Böhlke, Smith, and Miller, 2006). Isotope analysis is one such approach used to identify the relative importance of sources that are isotopically distinct such as nitrate and ammonium and the changes of isotope ratios that often occur in the biological cycling of nitrogen in predictable directions (KendaII, Elliott, and Wankel, 2007). However, there are some problems on the implementation of isotopes analysis that evoke controversy, such as the overlapping of isotopic compositions in different sources, the spatial and temporal variations in isotopic composition and the blurring of distinctive isotopic composition by isotope fractionation. New approaches try to minimize these problems, as in the case of a multi-isotope-multi tracer approach that tracks trace elements to different sources of nitrate giving a myriad of environmental variability inherent to natural systems (Kendall et al., 2007).

There are two different approaches applying nitrogen stable isotopes on groundwater, which are complementarity used: natural abundance and tracer methods, also known as ${ }^{15} \mathrm{~N}$ labeling experiments. The natural abundance approach reveals intrinsic information through rates of the predominant biogeochemical processes of the nitrogen cycle that incorporate large spatial and temporal variation of the processes with minimal alteration of the studied system (Hamilton and Ostrom, 2007). On the contrary, tracer methods offer primarily the study of rates experiments of elemental cycling on short incubations, which add around $10 \%$ of the 
ambient source concentration of ${ }^{15} \mathrm{~N}$-compound and are often best conducted in situ with the aim to avoid any contamination of the samples (Hamilton and Ostrom, 2007). Studies have reported the use of ${ }^{15} \mathrm{~N}$ labelling experiments in a wide range of aquatic ecosystems (Mulholland et al., 2004). The discovery of anammox was also accomplished in natural systems by using direct $\delta^{15} \mathrm{~N}$ tracer measurements. Currently, this ${ }^{15} \mathrm{~N}$ isotopic labelling has become a powerful tool to trace denitrification and anammox rates (Holtappels, Lavik, Jensen and Kuypers, 2011), but it cannot be used in the environment. The denitrification and anammox processes establish an unique labelling pattern, where anammox produces dinitrogen by one to one pairing of nitrogen from nitrite and ammonium (Strous et al., 1999), while denitrification generates nitrous oxide and dinitrogen through random pairing of nitrogen atoms during reduction of nitrogen oxide (Holtappels et al., 2011). Therefore, denitrification and anammox activity may be proved with the formation of ${ }^{15} \mathrm{~N}^{14} \mathrm{~N}$ $\left({ }^{29} \mathrm{~N}_{2}\right)$ rather than ${ }^{15} \mathrm{~N}^{15} \mathrm{~N}\left({ }^{30} \mathrm{~N}_{2}\right)$ in the laboratory (Dale et al., 2009). It is important, however, to develop an analytical tool by using a natural label of ${ }^{15} \mathrm{~N}$ and ${ }^{14} \mathrm{~N}$ isotopes for the determination of these processes without disturbance in natural systems.

In addition, the invention of right analytical method becomes more complicated since the availability of $\mathrm{NO}_{2}^{-}$pool may also cause the partitioning of nitrite between denitrification and DNRA. Thus, DNRA processes can be involved in anoxic tracer incubations due to the direct conversion of nitrite to ammonium in where the production of ${ }^{30} \mathrm{~N}_{2}$ may occur via anammox whether there is significant rates of DNRA by combining the DNRA substrate ${ }^{15} \mathrm{NO}_{2}{ }^{-}$with the DNRA product ${ }^{15} \mathrm{NH}_{4}{ }^{+}$(Kartal et al., 2007). The coupled DNRA-anammox may occur in two forms: intracellular coupled DNRA-anammox in which DNRA and anammox are effectuated within the same cell and intercellular coupled DNRA-anammox where distinct organisms carry out the coupled DNRA-anammox by using a small ambient ammonium pool (Holtappels et al., 2011).
In order to understand the complexity of nitrogen tracer experiments, it is important to clarify that there are ten known nitrogen isotopes, the majority of them being radioactive. The stable ones are ${ }^{14} \mathrm{~N}$ and ${ }^{15} \mathrm{~N}$ with concentrations of $99.634 \%$ and $0.368 \%$ of the global nitrogen pool of the earth's atmosphere (Holtappels et al., 2011). Stable isotope compositions are defined in terms of delta $(\delta)$ values that are established in parts per mil $\left(\%_{0}\right)$ according to equation (10).

$$
\delta=\left[\left(\mathrm{R}_{\text {sample }} / \mathrm{R}_{\text {standard }}\right)-1\right] \times 1000 \% \text { o }
$$

The $\delta$ value is calculated by the comparison of the ratio $(R)$ between the sample and standard. By convention, $\mathrm{R}$ is the ratio of the heavy (less abundant) to the light isotope (most abundant) (i.e. ${ }^{15} \mathrm{~N} /{ }^{14} \mathrm{~N}$ for nitrogen). The ratio standards are determined by the reference standard such as Vienna Pee Dee Belemnite (VPDB) or Vienna Standard Mean Ocean Water (VSMOW). The sample and standard have often very similar ratios of the two stable isotopes, which give a value very close to 1 . To emphasize this difference, the deviation from the value 1 is represented in per mil. For instance, the nitrogen isotopes ratios are calculated as the $\%$ difference to atmospheric $\mathrm{N}_{2}$ having a constant ${ }^{15} \mathrm{~N} /{ }^{14} \mathrm{~N}$ of $272 \pm 0.3$ (Coplen, Krouse, and Bohlke, 1992). The isotopes from an element contain mass differences, which may be interpreted as a mass-dependent isotope fractionation effect (Kendall and Caldwell, 1998). Equilibrium isotope exchange reaction and kinetic processes produce isotopic fractionations. The equilibrium fractionation processes are involved in reversible equilibrium reactions redistributing isotopes of an element to various compounds. The equilibrium fractionation factor $\alpha$ is used to express the fractionation associated with the equilibrium exchange reaction between two substances as shown in equation (11) where $k$ is the equilibrium constant and $n$ the number of exchanged atoms. Kinetic fractionation processes are associated with irreversible unidirectional kinetic reactions such as evaporation, dissociation, 
biologically mediated reactions and diffusion that establish the difference in the motility of the isotopic species. The kinetic isotope fractionation factor $\alpha$ describes the relative difference in the reaction rates constants $(k)$ of heavy and light isotopologues during the reaction, as shown in equation (12) for $\delta^{15} \mathrm{~N}$ and $\delta^{14} \mathrm{~N}$ (Mariotti et al., 1981).

$$
\begin{aligned}
& \alpha e q .=k 1 / n \\
& \alpha=14 k / 15 k
\end{aligned}
$$

Most biological reactions discriminate against the heavier isotope. Therefore, the definition of an isotope enrichment factor $(\varepsilon)$ is more convenient considering that it clearly highlights the range of variation (eq. 13):

$$
\varepsilon=(\alpha-1) \times 1000
$$

Many studies have taken advantage of isotope analysis of nitrogen $\left(\delta^{15} \mathrm{~N}\right)$ and subsequently, of oxygen $\left(\delta^{18} \mathrm{O}\right)$ over the last decades (Kendall, 1998; Clark et al., 2008). Whereas the use of only nitrogen isotopes analysis is challenging, as the $\delta$ ${ }^{15} \mathrm{~N}$ values of fertilizers and atmospheric deposition of existing nitrate and nitrate in soil are similar to the nitrogen forms in the aquatic ecosystems, the combination of $\delta^{15} \mathrm{~N}$ and $\delta^{18} \mathrm{O}$ analysis provides an important insight of nitrate sources involved in the nitrogen cycle (Kendall, 1998). Studies have reported the nitrogen isotopes fractionation of the different microbiological processes performed in the nitrogen cycle over the last decades. The fractionation of nitrification is often calculated from the rate determining step, which is the slower oxidation of ammonium to nitrite having a large $\delta^{15} \mathrm{~N}$ value ranging from 38 to -14 \%o (Mariotti et al., 1981). The transformation of nitrate to nitrogen gas via denitrification results in isotopic fractionations from +15 to $+30 \%$ o (Böttcher, Strebel, Voerkelius, and Schmidt, 1990). The reports of DNRA fractionation are lacking a range of isotopic effects (Kendall et al., 2007), whereas (McCready, Gould, and
Barendregt, 1983) used a kinetic fractionation demonstrating that produced ammonium has a lower $\delta^{15} \mathrm{~N}$ value than nitrate. There is little knowledge about the isotopic fractionation of anammox, but it is assumed that anammox and denitrification may have similar isotope fractionation. However, new evidences show that anammox preferentially removes dinitrogen from the ammonium pool with an isotope effect of +23.5 to $+29.1 \%$ in marine ecosystems according to Brunner et al. (2013).

\section{Conclusions}

Bearing in mind the issues described in the parts of this review, it is evident that more research on the detection of biogeochemical reactions of the nitrogen cycle in groundwater is needed in order to determine the impact of nitrogen pollutants on water supplies for human consumption. However, the field of measurements in environmental chemistry has shown that despite the limitations of effective methods that detect and quantify microbiological processes of nitrogen loss, there are some advances on the quantification of the rates of nitrogen elimination in groundwater by developing new analytical methods in the last few years. While the first methods for measurement of nitrogen compounds involved in the nitrogen cycle that came to light evidenced serious drawbac$\mathrm{ks}$, the use of ${ }^{15} \mathrm{~N}$-labelling experiments including in situ tracer experiments and multi-isotope-multi tracer approach has become a powerful tool investigating regulations of microbial redox reactions in the present. Nevertheless, although very elegant, this artificial isotopic labeling cannot be used in the environment, since introducing, for instance, ${ }^{15} \mathrm{NH}_{4}+$ or ${ }^{15} \mathrm{NOx}$ - in sufficient quantities into aquifers is practically impossible in natural conditions. As anammox and denitrification processes in the nitrogen cycle are the principal responsable in the removal of nitrogen compounds, the study of these processes are a priority, principally anammox reaction, which has not largely been explored. In addition, further research to estimate the kinetic 
rate parameters of the biogeochemical transformations in this complex reactions environment by using numerical models would be beneficial to establish new critical insight for the development of new methods for anammox and denitrification determination in groundwater and other natural systems.

\section{References}

Almasri, M. N. and Kaluarachchi, J. J. (2004). Assessment and management of long-term nitrate pollution of groundwater in agriculture-dominated watersheds. Journal Hydrology, 295, 225-245.

Aravena, R. and Robertson, W. D. (1998). Use of multiple isotope tracers to evaluate denitrification in ground water: study of nitrite from a large-flux septic plume. Journal Groundwater, 36(6), 975-982.

Böhlke, J. K., Smith, R. L. and Miller, D. N. (2006). Ammonium transport and reaction in contaminated groundwater: Application of isotope tracers and isotope fractionation studies. Journal Water Resources Research, 42, 1-19. DOI: https://doi.org/10.1029/2005WR004349

Böttcher, J., Strebel, O., Voerkelius, S. and Schmidt, H. L. (1990). Using isotope fractionation of nitrate-nitrogen and nitrate-oxygen for evaluation of microbial denitrification in a sandy aquifer. Journal Hydrology, 114, 413-424. DOI: https://doi.org/10.1016/0022-1694(90)90068-9

Brunner, B., Contreras, S., Lehmann, M. F., Matantseva, O., Rollog, M., Kalvelage, T., Klockgether, G., Lavik, G., Jetten, M. S. M., Kartal, B. and Kuypers, M. M. (2013). Nitrogen isotope effects induced by anammox bacteria. Journal Proceedings of the National Academy of Sciences of the United States of America, 110(47), 18994-18999. DOI: https://doi.org/10.1073/ pnas. 1310488110

Burt, T. P., Matchett, L. S., Goulding, K. W. T., Webster, C. P. and Haycock, N. E. (1999). Denitrification in a riparian buffer zones: the role of floodplain hydrology. Journal Hydrology Process, 13, 1451-1463. DOI: https://doi. org/10.1002/(SICI)1099-1085(199907)13:10< 1451::AID-HYP822>3.0.CO;2-W

Canter, L.W. (1996). Nitrates in groundwater. Boca Raton, FI, USA: Lewis Publishers Inc.

Castner, E., Leach, A., Leary, N., Baron, J., Compton, J., Galloway, J., Hastings, M., Kimiecik, J., Lantz-Trissel, J., De la Reguera, E. and Ryals, R. (2017). The nitrogen footprint tool network: a multilnstitution program to reduce nitrogen pollution. Mary Ann Liebert, Inc, 10(2), 79-88. DOI: http://dx.doi.org/10.1089/ sus.2017.29098.eac

Clark, I. D., Timlin, R., Bourbonnais, A., Jones, K., Lafleur, D. and Wickens, K. (2008). Origin and Fate of Industrial Ammonium in Anoxic Ground water: ${ }^{15} \mathrm{~N}$ Evidence for Anaerobic Oxidation Anammox. Journal Monitoring and Remediation, 28, 73-82. DOI: https://doi. org/10.1111/j.1745-6592.2008.00206.x

Christensen, T. H., Bjerq, P. L., Banwarth, S. A., Jakobsen, R., Heron, G. and Albrechtsen, $\mathrm{H}$. J. (2000). Characterization of redox conditions in groundwater contaminant plumes. Journal Contaminant Hydrology, 45, 165-241.

Christensen, T. H., Kjeldsen, P., Bjerq, P. L., Jensen, D. L., Christensen, J. B., Baun, A., Albrechtsen, H. J. and Heron, G. (2001). Review: Biogeochemistry of landfill leachate plumes. Journal Applied Geochemistry, 16(7-8), 659-718.

Codispoti, L. A. and Richards, F. A. (1976). An analysis of the horizontal regime of denitrification in the eastern tropical North Pacific. Journal Limnology and Oceanography, 5, 379-388.

Cole, J. A. and Brown, C. M. (1980). Nitrite reduction to ammonia by fermentative bacteria: a short circuit in the biological nitrogen cycle. FEMS Microbiology Letters Journal, 7, 65-72.

Coplen, T. B., Krouse, H. R. and Bohlke, J. K. (1992). Reporting of nitrogen isotope abundances-(Technical report). Journal Pure and Applied Chemistry, 4(6), 907-908. 
Dale, O. R., Tobias, C. R. and Song, B. (2009). Biogeographical distribution of diverse anaerobic ammonium oxidizing (anammox) bacteria in Cape Fear River estuary. Journal Environmental Microbiology, 11(5), 1194-1207. DOI: https:// doi.org/10.1111/j.1462-2920.2008.01850.x

Dalsgaard, T., Canfield, D. E., Petersen, J., Thamdrup, B. and Acuña-González, J. (2003). $\mathrm{N}_{2}$ production by the anammox reaction in the anoxic water column of Golfo Dulce, Costa Rica. Journal Nature, 422, 606-608.

Domenico, P. A. and Schwart, F. W. (1998). Physical and Chemical Hydrogeology. New York: Wiley.

Erler, D.V., Eyre, B. D. and Davison, L. (2008). The contribution of anammox and denitrification to sediment $\mathrm{N}_{2}$ production in a surface flow constructed Wetland. Journal Environmental Science and Technology, 42(24), 9144-9150.

Fields, S. (2004). Global Nitrogen: Cycling out of Control. Environmental Health Perspectives, 112(10), A556-A563.

Francis, A. J., Slater, J. M. and Dodge, C. J. (1989). Denitrification in deep sub-surface sediments. Journal Geomicrobiology, 7(2), 103-116. DOI: https://doi.org/10.1080/01490458909377853

Fuerst, J. and Sagulenko, E. (2011). Beyond the bacterium: planctomycetes challenge our concepts of microbial structure and function. Journal Nature Reviews Microbiology, 9, 403-413.

Ghaly, A. E. and Ramakrishnan, V. V. (2015) Nitrogen Sources and Cycling in the Ecosystem and its Role in Air, Water and Soil Pollution: A Critical Review. Journal Pollution Effects \& Control, 3(2), 2375-4397.

Hamilton, S.K., and Ostrom, N.E. (2007). Measurement of the stable isotope ratio of dissolved $\mathrm{N} 2$ in $15 \mathrm{~N}$ tracer experiments. Journal Limnology and Oceanography, 5, 233-240.

Holtappels, M., Lavik, G., Jensen, M. and Kuypers, M. (2011). ${ }^{15} \mathrm{~N}$ Labelling Experiments to Dissect the Contributions of Heterotrophic Denitrification and Anammox to $\mathrm{Ni}$ trogen Removal in the OMZ Waters of the
Ocean. In Methods in Enzymology edited by Martin G. Klotz, Burlington: Academic Press, 486, 223-251. DOI: https://doi.org/10.1016/ B978-0-12-381294-0.00010-9

Jahangir, M. R., Johnston, P., Addy, K., Khalil, M. I., Groffman, P. M. and Richards, K. G. (2013). Quantification of In Situ Denitrification Rates in Groundwater Below an Arable and a Grassland System. Journal Water Air Soil Pollution, 224(9), 1693-1701.

Kartal, B., Kuypers, M. M., Lavik, G., Schalk, J., Op den Camp, H. J. M., Jetten, M. S. M. and Strous, M. (2007). Anammox bacteria disguised as denitrifiers: nitrate reduction to dinitrogen gas via nitrite and ammonium. Journal Environmental Microbiology, 9(3), 635-642. DOI: https://doi. org/10.1111/j.1462-2920.2006.01183.x

Kehew, A. E. and Passero, R. N. (1990). pH and redox buffering mechanisms in a glacial drift aquifer contaminated by landfill leachate. Journal Groundwater, 28, 728-737.

Kendall, C. (1998). Tracing Nitrogen Sources and Cycling in Catchments. In C. Kendall and J. J. McDonnell (eds.), Isotope Tracers in Catchment Hydrology (pp. 519-576). Elsevier Science.

Kendall, C. and Caldwell, E. (1998). Fundamentals of Isotope Geochemistry. In C. KendaII and J. J. McDonnell (eds.), Isotope Tracers in Catchment Hydrology (pp. 51-86). Elsevier Science.

Kendall, C., Elliott, E. M. and Wankel, S. D. (2007). Tracing anthropogenic inputs of nitrogen to ecosystems. In R. H. Michener and K. Lajtha (eds.), Stable Isotopes in Ecology and Environmental Science (pp. 375449). Blackwell Publishing. DOI: https://doi. org/10.1002/9780470691854.ch12

Kobus, H. E. and Kinzelbach, W. (1989). Contaminant Transport in Groundwater. A.A. Rotterdam: Balkema.

Korom, S. F. (1992). Natural denitrification in the saturated zone: A review. Journal Water Resources Research, 28(6), 1657-1668. 
Lindenblatt, C. and Horn, H. (2010). Prozesswasser-Deammonifikation im SBR mit schwingendem Redoxpotential. Berichte aus Siedlungswasserwirtschaft Technische Universität München, 200, 135155.

Mariotti, A., Germon, J. C, Hubert, P., Kaiser, P., Letolle, R., Tardieux, A. and Tardieux, P. (1981) Experimental determination of nitrogen kinetic isotope fractionation: some principles; illustration for the denitrification and nitrification processes. Journal Plant Soil, 62(3), 413-430.

McCready R. G. L., Gould, W. D. and Barendregt, R. W. (1983). Nitrogen isotope fractionation during the reduction of $\mathrm{NO}_{3}{ }^{-}$to $\mathrm{NH}_{4}{ }^{+}$by Desulfovibrio sp. Canadian. Journal of Microbiology, 29(2), 231-234. DOI: https://doi. org/10.1139/m83-038

McMahon, P. B. and Böhlke, J. K. (2006). Regional patterns in the isotopic composition of natural and anthropogenic nitrate in groundwater, High Plains, USA. Journal Environmental Science and Technology, 40, 2965-2970.

Moore, T. A., Xing, Y., Brent, L., Lynch, M. D. J., Schiff, S., Robertson, W. D., Timlin, R., Lanza, S., Ryan, M. C., Aravena, R., Fortin, D., Clark, I. D. and Neufeld, J. D. (2011). Prevalence of Anaerobic Ammonium-Oxidizing Bacteria in Contaminated Groundwater. Journal Environmental Science and Technology, 45(17), 7217-7225.

Morris, J. T., Whiting, G. J. and Chapelle, F. H. (1988). Potential denitrification rates in deep sediments from the South-eastern Coastal Plain. Journal Environmental Sciences Technology, 22(7), 832-836.

Mulder, A., Van de Graaf, A. A., Robertson, L. A. and Kuenen, J. G. (1995). Anaerobic ammonium oxidation discovered in a denitrifying bed reactor. FEMS Microbiology and Ecology Journal, 16(3), 177-183. DOI: https://doi. org/10.1016/0168-6496(94)00081-7

Mulholland, P. J., Valett, H. M., Webster, J. R. Thomas, S. A., Cooper, L, W., Hamilton, S. K. and Peterson, B. J. (2004). Stream denitrification and total nitrate uptake rates measured using a field ${ }^{15}-\mathrm{N}$ tracer addition approach. Journal Limnology and Oceanography, 49, 809-820.

Rivett, M. A., Buss, S. R., Morgan, P., Smith, W. N. and Bemmet, C. D, (2008). Nitrate attenuation in groundwater: A review of biochemical controlling processes. Journal Water Research, 42, 4215-4232.

Sampat, P. (2000). Deep Trouble: the hidden threat of groundwater pollution. Washington, D. C.: Worldwatch Institute.

Schilling, K. E. (2002). Occurrence and distribution of ammonium in lowa groundwater. Journal Water Environment Research, 74, 177-186.

Schmidt, I., Sliekers, O., Schmid, M., Cirpus, I., Strous, M., Bock, E., Kuenen, J. G. and Jetten, S. M. (2002). Aerobic and anaerobic ammonia oxidizing bacteria- competitors or natural partners. FEMS Microbiology ECOlogy Journal, 39(3), 175-181. https://doi.org/10.1111/j.1574-6941.2002.tb00920.x

Schubert, C. J., Durisch-Kaiser, E., Wehrli, B., Thamdrup, B., Lam, P. and Kuypers, M. M. (2006). Anaerobic ammonium oxidation in a tropical freshwater system (Lake Tanganyika). Journal Environmental Microbiology, 8(10), 1857-1863. DOI: https://doi. org/10.1111/j.1462-2920.2006.01074.x

Seitzinger, S., Harrison, J. A., Böhlke, J. k., Bouwman, A. F., Lowrance, R., Peterson, B., Tobias, C. and Van Drecht, G. (2006). Denitrification across landscapes and waterscapes: a synthesis. Journal Ecological Applications, 16(6), 2064-2090.

Simonin, M., Le Roux, X., Poly, F., Lerondelle, C., Hungate, B. A., Nunan, N., Niboyet, A. (2015). Coupling Between and Among Ammonia Oxidizers and Nitrite Oxidizers in Grassland Mesocosms Submitted to Elevated $\mathrm{CO}_{2}$ and Nitrogen Supply. Journal Microbial Ecology, 70(3), 809-818.

Song, B. K. and Tobias, C. R. (2011). Molecular and stable isotope methods to detect and measure anaerobic ammonium oxidation (anammox) in 
aquatic ecosystems. Methods in Enzymology, 496, 63-89.

Spalding, R. F., Exner, M. E., Martin, G. E. and Snow, D. D. (1993). Effects of sludge disposal on groundwater nitrate concentrations. Journal Hydrology, 142, 213-228. DOI: https://doi. org/10.1016/0022-1694(93)90011-W

Strouss, M., Van Gerven, E., Zhen, P., Kuenen, J. G. and Jetten, M. S. M. (1999). Ammonium removal from concentrated waste streams with anammox process in different reactor configurations. Journal Water Resources, 31(8), 1955-1962. DOI: https://doi.org/10.1016/ s0043-1354(97)00055-9

Sumner, D. M., Rolston, D. E. and Bradner, L. A. (1998). Nutrient transport and transformation beneath an infiltration basin. Journal Water Environment Research, 70(5), 997-1004.

Thamdrup, B. and Dalsgaard, T. (2002). Production of $\mathrm{N}_{2}$ through Anaerobic Ammonium Oxidation Couples to Nitrate Reduction in Marine Sediments. Journal Applied and Environmental Microbiology, 63(3), 1312-1318.

Twort, A. C., Ratnayaka, D. D., and Brandt, M. J. (2000). Water Supply. London: Arnold with IWA Publishing.

Tobias, C. R., Macko, S. A., Anderson, I. C., Canuel, E. and Harvey, J. W. (2001). Tracking the fate of a high concentration groundwater nitrate plume through the fringing marsh: A combined groundwater tracer and in situ isotope enrichment study. Journal Limnology and Oceanography, 46(8), 1977-1989.

Tiedje, J. M. (1988). Ecology of denitrification and dissimilatory nitrate reduction to ammonium. In A. J. Zehnder (ed.), Biology of anaerobic microorganisms (pp. 179-244). New York: John Wiley and Sons.
Umweltbundesamt (UBA) (2014). Reactive nitrogen in Germany: causes and effects - measures and recommendations. Retrieved from https:// www.umweltbundesamt.de/sites/default/files/ medien/378/publikationen/reactive nitrogen in germany $0 . p d f$

United States Environmental Protection Agency (U.S EPA) (2017). Drinking water contaminants-standards and regulations.

Vajrala, N., Martens-Habbena, W., Sayavedra-Soto, L., Schauer, A., Bottomley, P. J., Stahl, D. A. and Arp, D. J. (2013). Hydroxylamine as an intermediate in ammonia oxidation by globaIly abundant marine archaea. Journal Proceedings of the National Academy of Sciences of the United States of America, 110(3), 1006-1011.

Vitousek, P. M., Aber, J. D, Howarth, R. W., Likens, G. E., Matson, P. A., Schindler, D. W., Schlesinger, W. H. and Tilman, D. G. (1997). Human alteration of the global nitrogen cycle: Sources and consequences. Journal Ecology Applications, 7(3), 737-750.

Wakida, F. T. and Lerner, D. N. (2005). Non-agricultural sources of groundwater nitrate: a review case study. Journal Water Resources, 39, 3-16.

Widory, D., Kloppmann, W., Chery, L., Bonnin, J., Rochdi, H. and LucGuinamant, J. (2004). Nitrate in groundwater: an isotopic multi-tracer approach. Journal Contaminant Hydrology, 72, 165-188. DOI: https://doi.org/10.1016/j. jconhyd.2003.10.010

Zhu, G., Wang, S., Wang, Y., Wang, C., Risgaard-Petersen, N., Jetten, M. S. M. and Yin, C. (2011). Anaerobic ammonia oxidation in a fertilized paddy soil. Multidisciplinary Journal of Microbial Ecology, 5(12), 1905-1912. 